\title{
Divergent Cytotoxic and Metabolically Stimulative Functions of Sigma-2 Receptors: Structure-Activity Relationships of 6-Acetyl-3- (4-(4-(4-fluorophenyl)piperazin-1-yl)butyl)benzo[d]oxazol-2(3H)-one (SN79) Derivatives ${ }^{\text {[ }}$
}

\author{
Hilary E. Nicholson, Walid F. Alsharif, Anthony B. Comeau, Christophe Mesangeau, \\ Sebastiano Intagliata, Marco Mottinelli, Christopher R. McCurdy, and Wayne D. Bowen \\ Department of Molecular Pharmacology, Physiology, and Biotechnology, Brown University, Providence, Rhode Island \\ (H.E.N., A.B.C., W.D.B.); Department of BioMolecular Sciences, School of Pharmacy, University of Mississippi, University, \\ Mississippi (W.F.A., C.M., C.R.M.); and Department of Medicinal Chemistry, College of Pharmacy, University of Florida, \\ Gainesville, Florida (S.I., M.M., C.R.M.)
}

Received September 19, 2018; accepted November 26, 2018

\begin{abstract}
Sigma-2 receptors, recently identified as TMEM97, have been implicated in cancer and neurodegenerative disease. Structurally distinct sigma-2 receptor ligands induce cell death in tumor cells, linking sigma-2 receptors to apoptotic pathways. Recently, we reported that sigma-2 receptors can also stimulate glycolytic hallmarks, effects consistent with a prosurvival function and upregulation in cancer cells. Both apoptotic and metabolically stimulative effects were observed with compounds related to the canonical sigma-2 antagonist SN79. Here we investigate a series of 6-substituted SN79 analogs to assess the structural determinants governing these divergent effects. Substitutions on the benzoxazolone ring of the core SN79 structure resulted in high-affinity sigma-2 receptor ligands $\left(K_{\mathrm{i}}=0.56-17.9 \mathrm{nM}\right)$, with replacement of the heterocyclic oxygen by $N$-methyl (producing $N$-methylbenzimidazolones) generally decreasing sigma-1 affinity
\end{abstract}

and a sulfur substitution (producing benzothiazolones) imparting high affinity at both subtypes, lowering subtype selectivity. Substitution at the 6-position with $\mathrm{COCH}_{3}, \mathrm{NO}_{2}, \mathrm{NH}_{2}$, or $\mathrm{F}$ resulted in ligands that were not cytotoxic. Five of these ligands induced an increase in metabolic activity, as measured by increased reduction of MTT (3-[4,5-dimethylthiazol-2-yl]-2,5-diphenyltetrazolium bromide) in human SK-N-SH neuroblastoma cells, further supporting a role for sigma-2 receptors in metabolism. Substitution with 6-isothiocyanate resulted in ligands that were sigma-2 selective and that irreversibly bound to the sigma-2 receptor, but not to the sigma-1 receptor. These ligands induced cell death upon both acute and continuous treatment $\left(\mathrm{EC}_{50}=7.6-32.8 \mu \mathrm{M}\right)$, suggesting that irreversible receptor binding plays a role in cytotoxicity. These ligands will be useful for further study of these divergent roles of sigma-2 receptors.
This work was supported by a National Institutes of Health (NIH) National Institute of General Medical Sciences T32 Predoctoral Pharmacology Training Grant [1-T32-GM077995] (H.E.N.); NIH National Institute of General Medical Sciences R25 Initiative for Maximizing Student Development Grant [R25GM083270] (H.E.N.); Brown University Pharmacia Pre-doctoral Fellowship (H.E.N.); National Institute on Drug Abuse Postdoctoral T32 Training Grant [5T32-DA-016184] (A.B.C.); NIH National Institute on Drug Abuse Grant [R01-DA023205] (W.F.A., C.M., C.R.M.); NIH National Institute of General Medical Sciences Grant [P20-GM-104932] (W.F.A., C.M., C.R.M.); The State of Florida and Office of the Provost at the University of Florida (S.I., M.M., C.R.M.); and the Upjohn Professorship in Pharmacology, Brown University (W.D.B.). No potential conflicts of interest relevant to this article are reported.

Part of this work was presented as follows: Nicholson HE, Alsharif W, McCurdy CR, and Bowen WD (2015) Evaluation of structural changes in SN79derived sigma-2 receptor modulators: effect on apoptotic efficacy in SK-N-SH neuroblastoma. Proceedings of the 106th Annual Meeting of the American Association for Cancer Research; 2015 April 18-22; Philadelphia, PA. American Association for Cancer Research, Philadelphia, PA. abstract \#2440. https://doi.org/10.1124/jpet.118.253484.

S This article has supplemental material available at jpet.aspetjournals.org.

\section{Introduction}

The sigma-2 receptor is a $21.5-\mathrm{kDa}$ protein, recently identified as the known protein TMEM97 (Hellewell and Bowen, 1990; Hellewell et al., 1994; Alon et al., 2017). Because of its upregulation in tumors compared with healthy tissue, the sigma-2 receptor (sigma-2R/TMEM97) has been implicated in cancer cell proliferation as well as developed into a tool for tumor imaging (Vilner et al., 1995; Mach et al., 1997; Wheeler et al., 2000; Mach and Wheeler, 2009; Zeng et al., 2011; Shoghi et al., 2013). Additionally, a connection between sigma-2 receptors and Alzheimer's disease has been described (Izzo et al., 2014a,b; Sahlholm et al., 2015; Yi et al., 2017). The sigma-2 receptor may also have some relationship to progesterone receptor membrane component 1 (PGRMC1), though the two proteins are not synonymous as initially

ABBREVIATIONS: CM572, 3-(4-(4-(4-fluorophenyl)piperazin-1-yl)butyl)-6-isothiocyanatobenzo[d]oxazol-2(3H)-one; CM764, 6-acetyl-3-(4-(4-(2-amino-4fluorophenyl)piperazin-1-yl)butyl)benzo[d]oxazol-2(3H)-one; DTG, 1,3-di-o-tolylguanidine; FBS, fetal bovine serum; $K_{\mathrm{d}}$, dissociation constant; $K_{\mathrm{i}}$, inhibition constant; MTT, 3-[4,5-dimethylthiazol-2-yl]-2,5-diphenyltetrazolium bromide; NCS, isothiocyanate substituent; NMe, N-methyl substituent; PGRMC1, progesterone receptor membrane component 1; PhNCS, phenyl isothiocyanate; SN79, 6-acetyl-3-(4-(4-(4-fluorophenyl)piperazin-1-yl)butyl)benzo[d]oxazol-2(3H)-one. 
proposed (Xu et al., 2011; Abate et al., 2015; Chu et al., 2015). They are both upregulated in cancer, both appear to be involved in the regulation of cell viability, and both are largely colocalized in cells, and the isolation of PGRMC1 was achieved using a sigma-2-selective probe. Thus, it is imperative that the pharmacology of the sigma-2 receptor be further developed and described to understand the pathways, mechanisms, and functions associated with it.

The functional classification of sigma-2 receptors is not standardized, with different investigators preferring different criteria for characterization. Generally, agonists of the sigma2 receptor are considered to induce programmed cell death. Cleavage of Bid, caspase-3 activation, induction of an immediate rise in cytosolic calcium, and positive terminal deoxynucleotidyl transferase-mediated dUTP nick end labeling (TUNEL) staining have been proposed as markers of sigma2 receptor agonist activity (Vilner and Bowen, 2000; Crawford and Bowen, 2002; Hazelwood and Bowen, 2006; Wang and Bowen, 2006; Zeng et al., 2014; Nicholson et al., 2015). Recently, we described a novel function of sigma-2 receptors, where a sigma-2 receptor ligand, CM764, induced an increase in various markers of glycolytic cellular metabolism as initially assessed by an increase in MTT reduction, without inducing changes in cell viability or cell proliferation (Nicholson et al., 2016). This effect was blocked by various sigma-2 receptor antagonists. In addition to the increase in MTT reduction, the effect comprised an increased level of $\mathrm{NAD}^{+} / \mathrm{NADH}$ and ATP, a marked decrease in basal reactive oxygen species level, and an increase in hypoxia-inducible factor $1 \alpha$, which may be connected to an observed increase in vascular endothelial growth factor expression (Nicholson et al., 2016). Thus, sigma-2 receptors may have a dual role with respect to cellular survival and may activate different pathways depending on the ligand. How this occurs is not clear. Interestingly, some of the effects of CM764 are similar to those mediated by PGRMC1, which has previously been associated with the sigma-2 receptor, as mentioned above (Xu et al., 2011; Abate et al., 2015; Chu et al., 2015). Notably, PGRMC1 has been implicated in the stimulation of vascular endothelial growth factor gene expression (Neubauer et al., 2009). PGRMC1 generally has proproliferative, prosurvival, and antiapoptotic effects in cells (Losel et al., 2008; Neubauer et al., 2009; Ahmed et al., 2010; Peluso et al., 2010). It is conceivable that PGRMC1 is involved in sigma-2/TMEM97 signaling in some way or that some sigma-2 ligands interact directly with PGRMC1. However, more studies would be necessary to address this.

A significant challenge for the study of sigma-2 receptors is the paucity of highly sigma-2-selective ligands. There exist several sigma-1-selective ligands, but ligands with high selectivity for sigma-2 over sigma-1 are relatively scarce. SN79 is a moderately selective sigma-2 receptor antagonist $\left(K_{\mathrm{i}}=7\right.$ and $28 \mathrm{nM}$ at sigma-2 and sigma-1, respectively) (Kaushal et al., 2011). Here, we characterize a novel series of SN79 analogs with single-element variations at the 6-position of the benzoxazolone, $N$-methylbenzimidazolone, and benzothiazolone heterocyclic systems. The study sought to determine a structural foundation for sigma-2 receptor affinity and selectivity. Furthermore, both cytotoxic effects and metabolic stimulative effects were induced by compounds within the same SN79-related structural class in various cell lines. CM572 induced programmed cell death (Nicholson et al., 2015), whereas CM764 induced metabolic stimulation (Nicholson et al., 2016). Thus, we further explored structural determinants of these divergent effects within this class. The study provides further evidence supporting a dual role of the sigma-2 receptor and provides a foundation from which to design targeted sigma-2 receptor ligands that are highly selective and result in inclusion in a predicted functional class.

\section{Materials and Methods}

Compound Syntheses. The synthesis and characterization of compounds are described in the supplemental information to this article (Supplemental Material).

Radioligand Binding Assays. Radioligand competition binding assays were performed as previously described (Nicholson et al., 2015). Briefly, $150 \mu \mathrm{g}$ of rat liver membrane protein was incubated for 120 minutes at $25^{\circ} \mathrm{C}$ in $20 \mathrm{mM}$ HEPES, $\mathrm{pH} 7.4$, with varying concentrations of each novel ligand and $3 \mathrm{nM}\left[{ }^{3} \mathrm{H}\right](+)$-pentazocine (PerkinElmer, Waltham, MA) for measuring sigma-1 receptors or $5 \mathrm{nM}$ $\left[{ }^{3} \mathrm{H}\right] \mathrm{DTG}$ (PerkinElmer) (in the presence of $100 \mathrm{nM}$ unlabeled (+)-pentazocine to mask sigma-1 receptors) to measure sigma-2 receptors in a final volume of $0.5 \mathrm{ml}$. Haloperidol $(10 \mu \mathrm{M})$ was used to determine nonspecific binding. After incubation, assays were terminated by

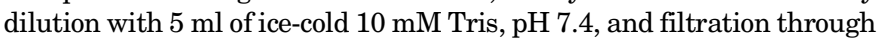
$0.5 \%$ polyethyleneimine-soaked fiberglass filters using a Brandel Cell Harvester (Brandel, Gaithersburg, MD) and two additional 5-ml washes in the same buffer. GraphPad Prism 6 software (GraphPad Software, La Jolla, CA) was used to determine $K_{\mathrm{i}}$ values with $\left[{ }^{3} \mathrm{H}\right](+)$-pentazocine $\left(K_{\mathrm{d}}=7.5 \mathrm{nM}\right)$ at sigma-1 receptors in rat liver homogenates and $\left[{ }^{3} \mathrm{H}\right]$ DTG $\left(K_{\mathrm{d}}=17.9 \mathrm{nM}\right)$ at sigma-2 receptors in rat liver homogenates (Hellewell et al., 1994).

For irreversible binding studies, $0.3 \mathrm{mg}$ protein $/ \mathrm{ml}$ membrane homogenate was treated with the indicated concentration of each isothiocyanate-substituted ligand individually for 60 minutes in $20 \mathrm{mM}$ HEPES, $\mathrm{pH} 7.4$, at $25^{\circ} \mathrm{C}$. This preparation was then diluted to $0.018 \mathrm{mg}$ protein/ml using ice-cold $20 \mathrm{mM}$ HEPES and centrifuged for 10 minutes at $37,000 \mathrm{~g}$. The pellet was resuspended to the original volume with ice-cold buffer and centrifuged again, and then resuspended again to the original volume. Noncovalently bound ligand was then allowed to dissociate during a 60 -minute incubation at $25^{\circ} \mathrm{C}$ prior to centrifugation of the preparation at $37,000 \mathrm{~g}$ for 10 minutes and resuspension of the pellet in $50 \mathrm{mM}$ Tris, $\mathrm{pH} 8.0$, to a concentration of $0.6 \mathrm{mg} / \mathrm{ml}$. This homogenate was used directly in binding studies at a final protein concentration of $0.3 \mathrm{mg}$ protein $/ \mathrm{ml}$ in $0.5 \mathrm{ml}$ total volume in incubation with $\left[{ }^{3} \mathrm{H}\right](+)$-pentazocine and $\left[{ }^{3} \mathrm{H}\right] \mathrm{DTG}$ [with unlabeled (+)-pentazocine] to determine the recovery of sigma-1 and sigma-2 binding sites, respectively. Control membranes were treated in the same manner without exposure to ligand. This membrane preparation procedure was able to dissociate $500 \mathrm{nM} \mathrm{SN79}$ from both sigma-1 and sigma-2 receptors, indicating successful removal of nonirreversibly bound ligand.

Cell Culture. Human SK-N-SH neuroblastoma cells (American Type Culture Collection, Manassas, VA) were cultured in minimum essential medium (Gibco, Grand Island, NY) containing 10\% fetal bovine serum (FBS), $10 \mathrm{mg} / \mathrm{l}$ human insulin, and $1 \times$ Pen-Strep (Gibco) in a humidified atmosphere at $37^{\circ} \mathrm{C}$ and $5 \% \mathrm{CO}_{2}$. Cells were passaged at $70 \%$ confluency.

Cell Viability and Metabolic Stimulation Assays. Cell viability was measured using MTT assays (Trevigen, Gaithersburg, MD). Cells were plated in 96-well plates at 15,000 cells/well and allowed to attach overnight. Cells were then treated with the indicated concentrations of ligand in a final volume of $100 \mu \mathrm{l}$ for 24 hours. After this period, $10 \mu \mathrm{l}$ of MTT Reagent was added to each well and allowed to be metabolized for 3 hours at $37^{\circ} \mathrm{C}$, then $100 \mu \mathrm{l}$ of MTT Detergent Reagent was added and allowed to solubilize formazan crystals and cell membranes for 2 additional hours. Absorbance was then read at $570 \mathrm{~nm}$. A decrease in absorbance was indicative of a loss of viable cells, and the percentage of cytotoxicity was calculated using the 
percentage loss in formazan formation in treated cells compared with untreated cells by the following formula (O.D., optical density):

$\%$ Cytotoxicity $=$

$$
\begin{aligned}
& 100-[(\text { O.D. treated cells }- \text { O.D. media blank }) \\
& /(\text { O.D. untreated control cells } \\
& - \text { O.D. media blank }) \times 100]
\end{aligned}
$$

$\mathrm{EC}_{50}$ values for dose-response curves were determined using GraphPad Prism 6 software (GraphPad Software).

For acute treatments, cells were treated with ligand for 60 minutes and then washed twice with fresh ligand-free medium to remove any nonirreversibly bound ligand. Fresh ligand-free medium $(100 \mu \mathrm{l})$ was then added to each well and allowed to incubate for 24 hours at $37^{\circ} \mathrm{C}$ prior to MTT assay, as described above.

Some compounds in this study were found to produce an increase in MTT reduction relative to control, as opposed to a decrease, in the 24-hour period of incubation. This is indicative of a stimulation in cellular metabolism. Metabolic stimulation was represented as the percentage change in MTT reduction and was calculated using the following formula:

$\%$ Change in MTT Reduction $=$

$[100 \times($ O.D. treated cells - O.D. media blank $)$

$$
\begin{aligned}
& \text { / (O.D. untreated control cells } \\
& \text { - O.D. media blank)] - } 100
\end{aligned}
$$

\section{Results}

Binding Affinity at Sigma-1 and Sigma-2 Receptors. SN79 was used as the lead compound in this study. SN79 (Table 1) has a benzoxazolone heterocycle, where $\mathrm{X}=\mathrm{O}$. Analogous benzothiazolones $(\mathrm{X}=\mathrm{S})$ and $N$-methylbenzimidazolones $(\mathrm{X}=\mathrm{NMe})$ were synthesized. Within the three heterocyclic families, various substitutions at the 6-position were examined, including compounds where $\mathrm{R}=$ acetyl $\left(\mathrm{COCH}_{3}\right)$, isothiocyanate (NCS), nitro $\left(\mathrm{NO}_{2}\right)$, and amine $\left(\mathrm{NH}_{2}\right)$. All ligands were examined for their ability to bind sigma-1 and sigma- 2 receptors using $\left[{ }^{3} \mathrm{H}\right](+)$-pentazocine to measure sigma- 1 receptors and $\left[{ }^{3} \mathrm{H}\right] \mathrm{DTG}$ to measure sigma-2 receptors in the presence of unlabeled (+)-pentazocine to mask sigma-1 receptors, as described in Materials and Methods. Results are summarized in Table 1.

When ligands with the same $\mathrm{R}$ group were compared, there existed a trend toward a loss of high-affinity binding at sigma1 receptors for compounds with NMe X-group substitutions. This was most clearly exemplified with WA403 $\left(\mathrm{R}=\mathrm{NH}_{2}\right)$ [and to a lesser extent with $\mathrm{NF} 7\left(\mathrm{R}=\mathrm{COCH}_{3}\right)$, where there is a striking rightward shift in the sigma-1 binding competition curves for the NMe-substituted ligand when compared with the other ligands with $\mathrm{R}=\mathrm{NH}_{2}$ and either $\mathrm{X}=\mathrm{O}$ or $\mathrm{X}=\mathrm{S}$, as demonstrated in Fig. 1. When $\mathrm{X}=\mathrm{NMe}$, the sigma-1 affinity was decreased by at least 6.5 -fold for $\mathrm{R}=\mathrm{COCH}_{3}$ in the same comparisons. When $\mathrm{R}=\mathrm{NO}_{2}$, the $\mathrm{X}=\mathrm{NMe}$ substitution still

TABLE 1

Binding affinities of SN79 derivatives at sigma-1 and sigma-2 receptors

Radioligand competition binding assays were performed using $\left[{ }^{3} \mathrm{H}\right](+)$-pentazocine to measure sigma-1 receptors and $\left[{ }^{3} \mathrm{H}\right] \mathrm{DTG}$ in the presence of unlabeled $(+)$-pentazocine to measure sigma-2 receptors as described in Materials and Methods. Single-position changes to the core structure of SN79 resulted in drastic changes in affinity and selectivity at sigma-1 and sigma-2 receptors. Generally, changes in the $\mathrm{X}$ position determined selectivity, with $\mathrm{S}$ substitutions resulting in reduced selectivity and $\mathrm{O}$ substitutions resulting in increased selectivity for the sigma-2 receptor. R-group substitutions did not demonstrate a discernably consistent pattern across the ligand series. An accurate $\mathrm{K}_{\mathrm{i}}$

\begin{tabular}{|c|c|c|c|c|c|}
\hline \multirow[b]{2}{*}{ Ligand } & \multirow[b]{2}{*}{$\mathrm{X}$} & \multirow[b]{2}{*}{$\mathrm{R}$} & \multicolumn{2}{|c|}{ Sigma Binding Affinities ( $\mathrm{K}_{\mathrm{i}} \pm$ S.D.) } & \multirow[b]{2}{*}{ Sigma-1/Sigma-2 } \\
\hline & & & $\begin{array}{c}{\left[{ }^{3} \mathrm{H}\right](+)-\text {-Pentazocine }} \\
\text { Sigma-1 }\end{array}$ & $\begin{array}{l}{\left[{ }^{3} \mathrm{H}\right] \mathrm{DTG}} \\
\text { Sigma-2 }\end{array}$ & \\
\hline & & & \multicolumn{2}{|c|}{$\mathrm{nM}$} & \\
\hline SN79 & $\mathrm{O}$ & $\mathrm{COCH}_{3}$ & $28.0 \pm 3.39^{a}$ & $6.89 \pm 0.09^{a}$ & 4.06 \\
\hline CM572 & $\mathrm{O}$ & NCS & $\geq 10,000^{b}$ & $14.6 \pm 7.0^{b}$ & $>685$ \\
\hline CM458 & $\mathrm{O}$ & $\mathrm{NO}_{2}$ & $22.2 \pm 5.3$ & $0.56 \pm 0.38$ & 39.6 \\
\hline CM571 & $\mathrm{O}$ & $\mathrm{NH}_{2}$ & $15.5 \pm 2.4$ & $21.7 \pm 5.3$ & 0.7 \\
\hline NF7 & $\mathrm{NMe}$ & $\mathrm{COCH}_{3}$ & $183 \pm 13.9$ & $20.6 \pm 2.4$ & 8.9 \\
\hline WA404 & $\mathrm{NMe}$ & NCS & $449 \pm 44.4$ & $36.3 \pm 7.8$ & 12.4 \\
\hline WA402 & $\mathrm{NMe}$ & $\mathrm{NO}_{2}$ & $20.3 \pm 6.5$ & $7.4 \pm 3.0$ & 2.7 \\
\hline WA403 & $\mathrm{NMe}$ & $\mathrm{NH}_{2}$ & $2988 \pm 507$ & $17.9 \pm 8.0$ & 167 \\
\hline WA504 & $\mathrm{S}$ & $\mathrm{COCH}_{3}$ & $8.1 \pm 2.3$ & $2.5 \pm 2.7$ & 3.2 \\
\hline WA435 & $\mathrm{S}$ & NCS & $56.9 \pm 10.2$ & $2.0 \pm 1.5$ & 28.5 \\
\hline WA413 & $\mathrm{S}$ & $\mathrm{NO}_{2}$ & $6.1 \pm 1.0$ & $3.2 \pm 0.3$ & 1.9 \\
\hline WA416 & $\mathrm{S}$ & $\mathrm{NH}_{2}$ & $15.6 \pm 2.8$ & $3.9 \pm 0.5$ & 4.0 \\
\hline WA379 & $\mathrm{NMe}$ & $\mathrm{F}$ & $101 \pm 10.3$ & $6.1 \pm 1.7$ & 16.5 \\
\hline
\end{tabular}
value could not be determined for CM572 ( $\mathrm{X}=\mathrm{O}, \mathrm{R}=\mathrm{NCS}$ ) at sigma-1 receptors because of insolubility above $1 \mathrm{mM}$. However, $\sim 50 \%$ of total sigma-1 receptors were bound by $10,000 \mathrm{nM}$ CM572 compared with total available sigma-1 receptor binding capacity, as measured by $\left[{ }^{3} \mathrm{H}\right](+)$-pentazocine alone. The results are presented as the average \pm S.D. of $\mathrm{K}_{\mathrm{i}}$ values from at least three independent experiments for each ligand (except for CM572 at sigma-1 receptors). All experiments were performed in duplicate.

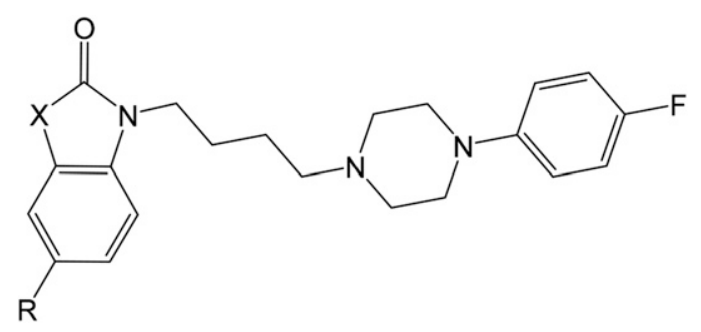

${ }^{a}$ Kaushal et al. (2011).

${ }^{b}$ Nicholson et al. (2015). 


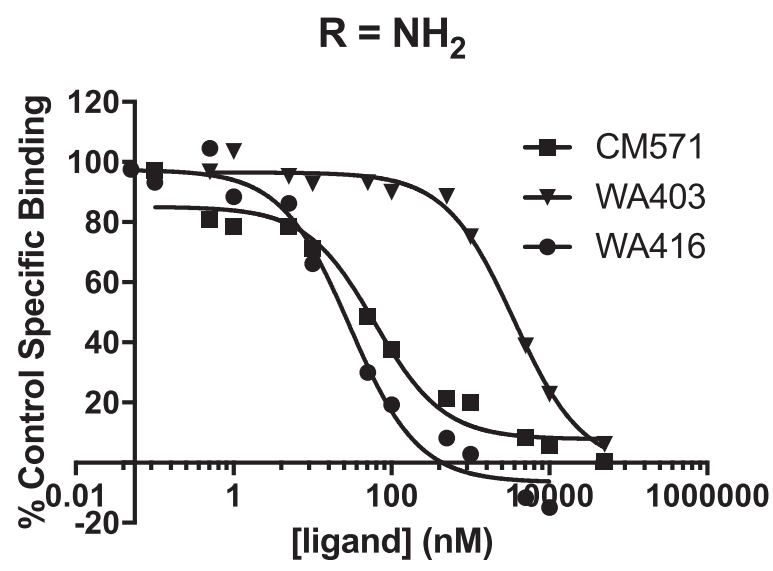

Fig. 1. Effect of X-group substitutions on sigma-1 receptor binding affinity. Affinity at sigma-1 receptors was determined by competition against $\left[{ }^{3} \mathrm{H}\right](+)$-pentazocine as described in Materials and Methods. $K_{\mathrm{i}}$ values for sigma-1 receptor binding of $\mathrm{R}=\mathrm{NH}_{2}$ substituted ligands were determined to be $15.5 \pm 2.4,2988 \pm 507$, and $15.6 \pm 2.8 \mathrm{nM}$, respectively, for CM571 $\left(\mathrm{X}=\mathrm{O}, \mathrm{R}=\mathrm{NH}_{2}\right)$, WA403 ( $\left.\mathrm{X}=\mathrm{NMe}, \mathrm{R}=\mathrm{NH}_{2}\right)$, and WA416 $(\mathrm{X}=$ $\mathrm{S}, \mathrm{R}=\mathrm{NH}_{2}$ ) substitutions. This series dramatically demonstrates the general loss of sigma-1 receptor affinity for $\mathrm{X}=\mathrm{NMe}$ substituted ligands compared with other X-group substitutions. Competition curves shown are an average of three independent experiments for CM571, five independent experiments for WA403, and three independent experiments for WA416. All experiments were performed in duplicate. The $K_{\mathrm{i}}$ values reported are an average \pm S.D. of the individual $K_{\mathrm{i}}$ value from each independent experiment.

demonstrated the lowest affinity binding compared with other $\mathrm{X}$-group substitutions; however, the shift was less drastic. For WA404 ( $\mathrm{R}=\mathrm{NCS}$ ) the NMe-substituted ligand bound sigma-1 receptors with approximately eight times lower affinity than the corresponding $\mathrm{X}=\mathrm{S}$ substitution (WA435). For CM572 $\left(\mathrm{R}=\mathrm{NCS}, \mathrm{X}=\mathrm{O}\right.$ ), a valid $K_{\mathrm{i}}$ value could not be determined at sigma-1 receptors due to the solubility limits of the compound. However, it is clear that CM572 $(\mathrm{X}=\mathrm{O}, \mathrm{R}=\mathrm{NCS})$ is an outlier in this series because of its lack of significant sigma-1 receptor binding and therefore its extreme selectivity.

Comparing ligands with the same X-group substitution allowed for a comparison of the effects of R-group substitutions on sigma-1 receptor binding affinity. Ligands with $R=$ NCS generally had a significantly decreased affinity for sigma-1 receptors compared with any other $\mathrm{R}$-group substitution. This is best demonstrated by CM572 $(\mathrm{R}=\mathrm{NCS}, \mathrm{X}=\mathrm{O})$, where the isothiocyanate-substituted ligand has a decrease in sigma-1 receptor binding affinity of over 500-fold when compared with any other R-group substitution, as shown in Fig. 2. For $\mathrm{X}=\mathrm{S}$ substitutions, there was at least a 3-fold loss of sigma-1 affinity for the isothiocyanate (WA435) substitution compared with the other R-group substitutions. As mentioned above, sigma-1 receptor binding affinity was not high for any ligand when $\mathrm{X}=\mathrm{NMe}$ (Fig. 1), and WA404 $(\mathrm{R}=\mathrm{NCS}, \mathrm{X}=\mathrm{NMe})$ had a low-affinity $K_{\mathrm{i}}$ value of $449 \mathrm{nM}$ at the sigma-1 receptor, although this was not the lowest affinity of the $\mathrm{X}=\mathrm{NMe}$ substituted ligands.

It is not immediately clear why, within each heterocyclic system, the R = NCS analogs would demonstrate lower affinity for sigma-1 compared with the other substituents. They do not covalently bind to the sigma-1 receptor (see below), presumably because of the lack of a properly oriented receptor nucleophile in or near the binding site. However, this would not necessarily affect sigma-1 binding affinity. It is possible that there are steric issues affecting the fit of the

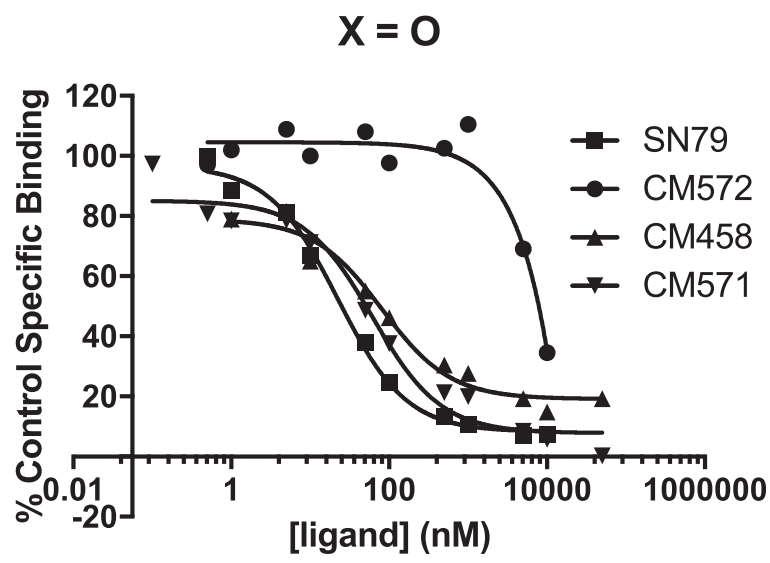

Fig. 2. Effect of R-group substitutions on sigma-1 receptor binding affinity. Affinity at sigma-1 receptors was determined by competition against $\left[{ }^{3} \mathrm{H}\right](+)$-pentazocine as described in Materials and Methods. Sigma-1 receptor binding affinity was significantly decreased when $\mathrm{R}=$ NCS for all X-group substitutions. This pattern is most clearly illustrated for $\mathrm{X}=\mathrm{O}$ substituted ligands, with CM572 $(\mathrm{X}=\mathrm{O}, \mathrm{R}=\mathrm{NCS})$ showing at least a 350-fold loss in sigma-1 receptor binding affinity compared with other R-group substitutions. $K_{\mathrm{i}}$ values for $\mathrm{X}=\mathrm{O}$ substituted ligands at sigma-1 receptors were determined to be $28.0 \pm 3.39^{*},>10,000,22.2 \pm$ 5.3 , and $15.5 \pm 2.4 \mathrm{nM}$ for SN79 $\left(\mathrm{X}=\mathrm{O}, \mathrm{R}=\mathrm{COCH}_{3}\right), \mathrm{CM} 572(\mathrm{X}=\mathrm{O}$, $\mathrm{R}=\mathrm{NCS}), \mathrm{CM} 458\left(\mathrm{X}=\mathrm{O}, \mathrm{R}=\mathrm{NO}_{2}\right)$, and CM571 $\left(\mathrm{X}=\mathrm{O}, \mathrm{R}=\mathrm{NH}_{2}\right)$, respectively. An accurate $K_{\mathrm{i}}$ value for CM572 $(\mathrm{X}=\mathrm{O}, \mathrm{R}=\mathrm{NCS})$ at sigma-1 receptors could not be determined due to insolubility above $1 \mathrm{mM}$; however, $\sim 50 \%$ of $\left[{ }^{3} \mathrm{H}\right](+)$-pentazocine binding sites remained with 10,000 nM CM572 present. The competition curves shown are an average of four independent experiments for SN79, two independent experiments for CM572, three independent experiments for CM458, and three independent experiments for CM571. All experiments were performed in duplicate. The $K_{\mathrm{i}}$ values reported are an average \pm S.D. of the individual $K_{\mathrm{i}}$ value from each independent experiment (*Kaushal et al., 2011).

isothiocyanate group into the binding pocket. Another possibility is that these ligands may assume a "flipped" binding conformation in the sigma-1 binding pocket. Electronic effects may also come into play, since sigma-1 affinity of the isothiocyanates is affected by the nature of the $\mathrm{X}$ moiety in the heterocycle. Further studies to determine ligand-bound $\mathrm{X}$-ray crystal structures would be needed to confirm these possibilities.

The effect of X-group substitutions on receptor affinity was not limited to the sigma- 1 subtype. When sigma- 2 affinities were compared, $\mathrm{X}=\mathrm{S}$ substituted ligands had generally high sigma-2 affinity compared with $\mathrm{X}=\mathrm{O}$ and $\mathrm{X}=\mathrm{NMe}$ substituted ligands. Ligands with varying $\mathrm{X}$-group substitutions and either $\mathrm{R}=\mathrm{NCS}$ (left panel) or $\mathrm{R}=\mathrm{NH}_{2}$ (right panel) are shown in Fig. 3 for sigma-2 receptor binding. WA435 $(\mathrm{R}=$ NCS, the $\mathrm{X}=\mathrm{S}$ ) showed at least a 7-fold increase in sigma-2 receptor affinity compared with other X-group substitutions (Fig. 3, left panel). Similarly, when $\mathrm{R}=\mathrm{NH}_{2}$, the sulfur $\mathrm{X}$ group substitution resulted in higher-affinity ligands compared with $\mathrm{X}=\mathrm{O}$ and $\mathrm{X}=\mathrm{NMe}$ substitutions (Fig. 3, right panel). Similar results were also observed when $\mathrm{R}=\mathrm{COCH}_{3}$. Since $\mathrm{X}=\mathrm{S}$ substitution resulted in ligands with sigma-2 receptor affinities that were between 2 and $4 \mathrm{nM}$, this indicates that the benzothiazolone heterocycle represents an optimal platform for further development of high-affinity sigma-2 ligands. Furthermore, the lower sigma-1 affinity of the $\mathrm{R}=$ NCS derivative resulted in WA435 having 28.5-fold selectivity for sigma-2 receptors.

Across all three heterocycles, $\mathrm{R}=\mathrm{NO}_{2}$ substitutions generally resulted in very high-affinity sigma-2 ligands, with $K_{\mathrm{i}}$ 

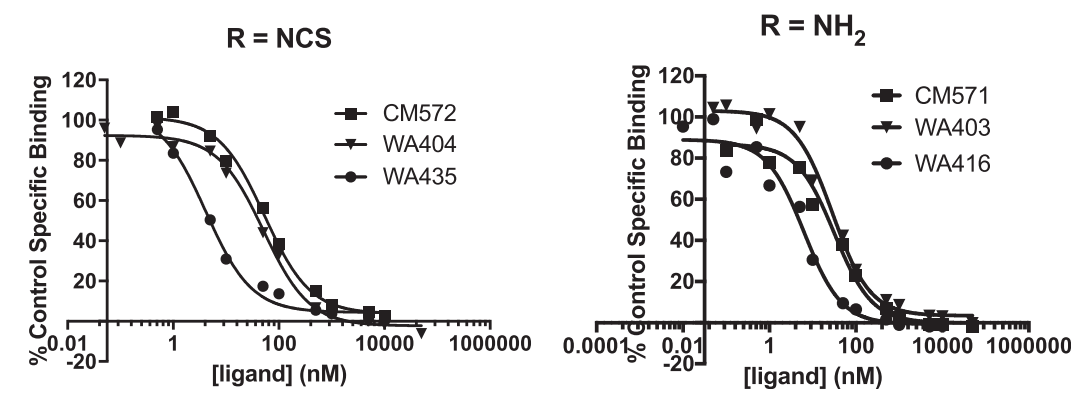

Fig. 3. Effect of X-group substitutions on sigma-2 receptor binding affinity. Affinity at sigma-2 receptors for ligands with varying $\mathrm{X}$ substituent (O, NMe, or $\mathrm{S}$ ) and either $\mathrm{R}=\mathrm{NCS}$ or $\mathrm{NH}_{2}$ was determined by competition against $\left[{ }^{3} \mathrm{H}\right] \mathrm{DTG}$ as described in Materials and Methods. Generally, X-group substitutions with sulfur resulted in ligands with very high sigma-2 receptor binding affinity, with $K_{\mathrm{i}}$ values ranging between 2 and $4 \mathrm{nM}$. This trend generally held true across R-group changes and was most drastically demonstrated by the WA435 $(\mathrm{X}=\mathrm{S}, \mathrm{R}=\mathrm{NCS})$ and WA416 $\left(\mathrm{X}=\mathrm{S}, \mathrm{R}=\mathrm{NH}_{2}\right)$ comparisons depicted here. For $\mathrm{R}=\mathrm{NCS}$ (left panel), WA435 (X=S, R = NCS) showed at least a 7-fold higher binding affinity compared with the other X group-substituted ligands. Similarly, for $\mathrm{R}=\mathrm{NH}_{2}$ (right panel), WA416 $\left(\mathrm{X}=\mathrm{S}, \mathrm{R}=\mathrm{NH}_{2}\right)$ showed at least a 4.5-fold higher binding affinity compared with the other X group-substituted ligands. Competition curves shown are an average of four independent experiments for CM572, six independent experiments for WA404, three independent experiments for WA435, three independent experiments for CM571, five independent experiments for WA403, and three independent experiments for WA416. All experiments were performed in duplicate.

values better than $8 \mathrm{nM}$. Of particular note is $\mathrm{CM} 458(\mathrm{X}=\mathrm{O}, \mathrm{R}=$ $\mathrm{NO}_{2}$ ), which exhibited subnanomolar affinity at sigma-2 receptors $\left(K_{\mathrm{i}}=0.56 \mathrm{nM}\right)$.

The variations in the $\mathrm{X}$ position that resulted in drastic effects on binding affinity at both sigma-1 and, to a lesser extent, sigma-2 receptor binding affinity naturally also demonstrated an effect on subtype selectivity of the ligands. It should be noted that all ligands demonstrated at least slightly selective binding for the sigma-2 receptor over the sigma-1 receptor except for CM571 $\left(\mathrm{X}=\mathrm{O}, \mathrm{R}=\mathrm{NH}_{2}\right)$. Generally, having an oxygen in the $\mathrm{X}$ position led to more highly sigma2 -selective ligands, whereas having a sulfur in this position generally decreased selectivity (Table 1). However, this trend was less closely adhered to than trends in binding at each individual receptor.

Overall, the modifications yielded five new compounds that have higher sigma-2 receptor binding affinity than the parent compound, with CM458 exhibiting 12.3-fold higher affinity than SN79. They also resulted in seven ligands that are significantly more selective for sigma-2 relative to sigma-1, compared with SN79. Notably, WA435, CM458, WA403, and CM572 were, respectively, 28.5-, 39.6-, 167-, and $>685$-fold selective for sigma-2 over sigma-1. This is a marked improvement over SN79, which was only 4-fold selective.

Irreversible Binding Capability at Sigma-1 and Sigma-2 Receptors. The isothiocyanate moiety was added with the idea of imparting irreversible binding capability to the ligands through potential nucleophilic attack from an amine or thiol group appropriately positioned in the binding pocket of the sigma-2 receptor. We have previously shown that CM572 (X = O, R = NCS) is able to irreversibly bind to the sigma-2 receptor (Nicholson et al., 2015). In the current study, we examined two additional $\mathrm{R}=$ NCS substituted ligands for their ability to irreversibly bind sigma- 1 and sigma-2 receptors. Figure 4 shows the results of ligand washout experiments. Both WA404 (X = NMe, R = NCS) and WA435 (X = S, $\mathrm{R}=\mathrm{NCS}$ ) were able to irreversibly bind sigma-2 receptors, with WA435 ( $\mathrm{X}=\mathrm{S}, \mathrm{R}=\mathrm{NCS})$ having a higher potency for irreversible binding (Fig. 4). This trend correlates with sigma-2 receptor binding affinity differences, as the $\mathrm{X}=\mathrm{S}$ substituted ligands have a higher affinity for sigma-2 receptors than the $\mathrm{X}=\mathrm{NMe}$ substituted ligands. Neither isothiocyanate potently irreversibly bound sigma- 1 receptors, although WA404 (X = NMe, R = NCS) did show some ability to irreversibly block sigma-1 receptor binding at high doses. Interestingly, despite the relatively higher affinity of WA435 for sigma- 1 receptors and saturation at the highest concentration examined (1000 nM), the compound was completely washed out of the receptor, confirming the lack of a suitable neighboring nucleophile in the sigma-1 receptor.

Effect of Acute and Continuous Exposure to Ligand on Cell Viability in SK-N-SH Neuroblastoma. One generally accepted criterion for the classification of a sigma-2 receptor ligand as an agonist is the ability to induce cell death. To classify the function of the ligands in this study, MTT cell viability assays were used to determine the efficacy and potency of the ability of each ligand to induce cell death in SK-N-SH neuroblastoma. The R-group substitution had the greatest effect on the ability of each ligand to induce cell death. The only compounds in the series with the ability to potently decrease cell viability were those with $R=$ NCS, regardless of $\mathrm{X}$-group substitution. Data for the most active compounds is depicted in Fig. 5. The isothiocyanate-substituted ligands all were able to induce a reduction in cell viability in the SK-N-SH neuroblastoma with an $\mathrm{EC}_{50}$ below $35 \mu \mathrm{M}$, with CM572 $(\mathrm{X}=$ $\mathrm{O}, \mathrm{R}=\mathrm{NCS}$ ) being the most potent with an $\mathrm{EC}_{50}$ of $7.6 \mu \mathrm{M}$, as previously reported (Nicholson et al., 2015). Isothiocyanates with other $\mathrm{X}$-group substitutions $(\mathrm{X}=\mathrm{NMe}$ and $\mathrm{X}=\mathrm{S})$ demonstrated less potent $\mathrm{EC}_{50}$ values $(\mathrm{WA} 404=30.4 \pm 1.1$ $\mu \mathrm{M}$ and WA435 $=32.8 \pm 1.1 \mu \mathrm{M})$. Some nonisothiocyanate ligands were also able to induce cell death, but were much less potent than the isothiocyanates. WA413 $\left(\mathrm{X}=\mathrm{S}, \mathrm{R}=\mathrm{NO}_{2}\right)$ reached $\sim 36 \%$ cytotoxicity at a dose of $50 \mu \mathrm{M}$ after 24 hours of treatment. An $\mathrm{EC}_{50}$ value for this ligand could not confidently be determined due to insolubility at high doses. WA402 (X = $\mathrm{NMe}, \mathrm{R}=\mathrm{NO}_{2}$ ) exhibited $<50 \%$ cell death at a concentration of $100 \mu \mathrm{M}$.

The radioligand binding study demonstrated that the isothiocyanate substitution imparted the ability of the ligands to irreversibly bind sigma-2 receptors in each heterocycle class, whereas sigma-1 receptor irreversible binding was not generally observed (Fig. 4). The effect of this irreversible binding on cell viability was further tested by treating SK-N-SH neuroblastoma with an acute 60 -minute pretreatment with the isothiocyanate ligands, followed by extensive washing and a 24 -hour incubation in fresh ligand-free media. 
A

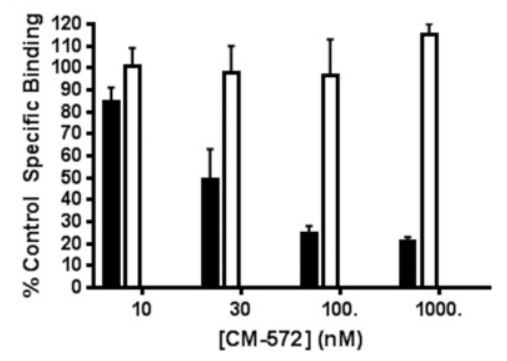

B

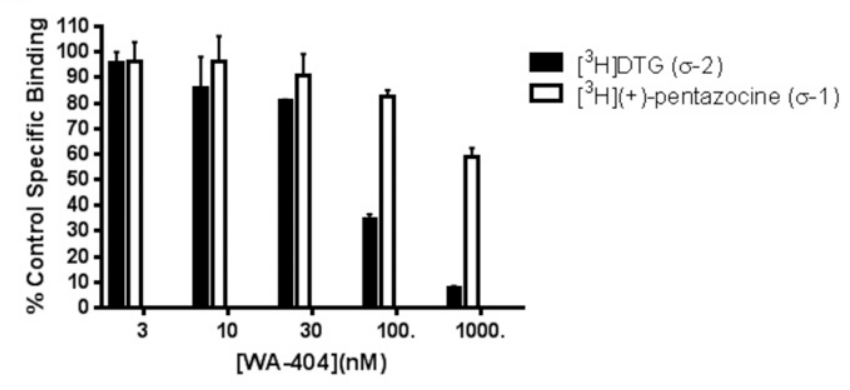

C

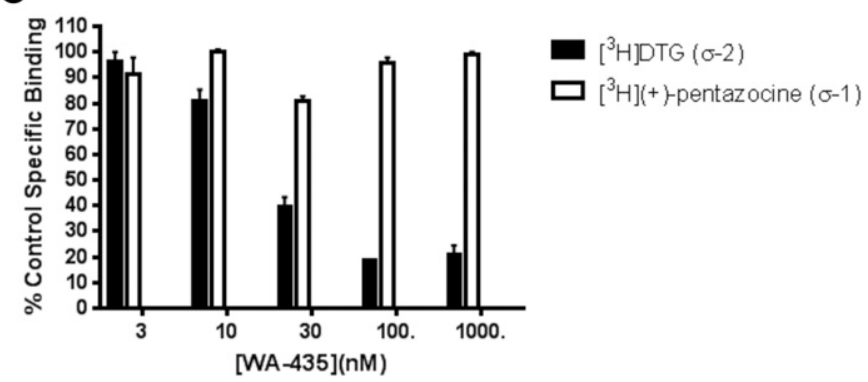

Fig. 4. Irreversible binding of isothiocyanate-substituted ligands at sigma-1 and sigma-2 receptors. Rat liver membrane homogenates were treated with isothiocyanate-substituted ligands for 60 minutes prior to washing to remove any reversibly bound ligand, as described in Materials and Methods. Recovery of sigma-1 and sigma-2 binding sites was then determined using $\left[{ }^{3} \mathrm{H}\right](+)$-pentazocine for sigma- 1 receptors and $\left[{ }^{3} \mathrm{H}\right] \mathrm{DTG}$ for sigma-2 receptors, as described in Materials and Methods. Data are presented as the percentage of total sigma receptors of each subtype recovered. CM572 (X $=\mathrm{O}, \mathrm{R}=\mathrm{NCS}$ ) (A) was previously shown to irreversibly bind sigma-2 receptors but not sigma-1 receptors (Nicholson et al., 2015). WA404 (X = NMe, R = NCS) (B) and WA435 (X = S, R = NCS) (C) also showed the ability to selectively and irreversibly bind sigma-2 receptors. WA404 (X = NMe, R= NCS) demonstrated some slight ability to irreversibly bind sigma-1 receptors, but only at high concentrations. The data shown are the average of at least two independent experiments for each condition, with each experiment performed in duplicate.

Cell viability was assessed after this period, and any induced cell death was attributed to ligand irreversibly bound and therefore continuously activating sigma-2 receptors throughout the 24-hour incubation without free ligand. Results are shown in Fig. 6. All isothiocyanate derivatives were found to continue to induce cell death after the acute 60-minute pretreatment, washing, and 24-hour incubation in media without free ligand. For both CM572 (X = O, R = NCS) and WA404 ( $\mathrm{X}=\mathrm{NMe}, \mathrm{R}=\mathrm{NCS}$ ), the acute treatment reached levels of cell death comparable to those of the 24-hour incubation with ligand, with no statistically significant differences between the two exposure times $(P=0.13$ and $P=0.056$ for comparison of the 24-hour incubation with ligand and the 60-minute acute treatment of CM572 and WA404,

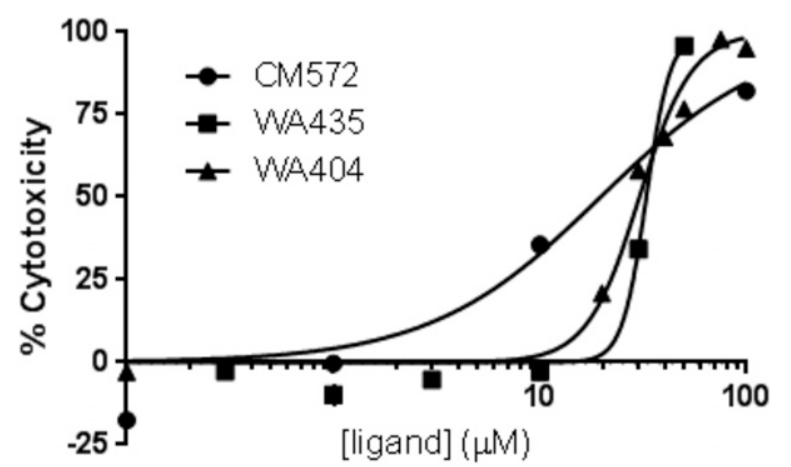

Fig. 5. Effect of isothiocyanate derivatives on cell viability of SK-N-SH neuroblastoma. SK-N-SH neuroblastoma cells were plated at 15,000 cells/well and allowed to attach overnight prior to dosing with indicated concentration of each ligand. Cells were incubated with the indicated compounds for 24 hours, prior to the determination of viable cells remaining using MTT assay, as described in Materials and Methods. Data are presented as percent cytotoxicity. All three isothiocyanate derivatives induced dose-dependent cell death. $\mathrm{EC}_{50}$ values were $7.6 \pm$ $1.7^{*}, 32.8 \pm 1.05$, and $30.4 \pm 1.13 \mu \mathrm{M}$, respectively, for CM572 $(\mathrm{X}=\mathrm{O}$, $\mathrm{R}=\mathrm{NCS}$ ), WA435 (X= S, R= NCS), and WA404 (X = NMe, R = NCS). The dose-response curves shown are an average of three independent experiments for each ligand, with each experiment performed using five replicates per condition. EC $_{50}$ values were determined from average cytotoxicity (*Nicholson et al., 2015).

respectively, using Student's $t$ test). Interestingly, for WA435 ( $\mathrm{X}=\mathrm{S}, \mathrm{R}=\mathrm{NCS}$ ) the efficacy of the ligand increased when treated acutely compared with the 24 hours of continuous exposure $(P=0.003$ for comparison of the two conditions, Student's $t$ test). It should be noted here that in our previous study using siramesine, removing siramesine (which cannot bind covalently to sigma receptors) after a 60-minute pretreatment of SK-N-SH neuroblastoma cells completely prevented the induction of cell death (Nicholson et al., 2016). This rules out the possibility that a 60 -minute acute exposure to sigma-2 agonist is enough time to commit to a cell death program, such that cell death would occur after subsequent removal of even a reversibly bound ligand.

When cell viability data from all the compounds are considered, the data clearly show that in order for the compounds in this SN79-related series to be potently cytotoxic, the isothiocyanate group must be present. This could indicate that irreversible binding to sigma-2 receptors is a requirement for cytotoxicity. However, another explanation for the efficacy of the isothiocyanate ligands is that the strong electron-withdrawing character of this moiety influences the receptor interaction such that the efficacy is altered. To discriminate between the effect of irreversible binding and the effect of the strong electron-withdrawing character of the isothiocyanate moiety on cell viability, an R-group substitution with fluorine was investigated to represent the strong electron-withdrawing character of the isothiocyanate but without the capability to irreversibly bind to the sigma-2 receptor. This ligand, WA379 $(\mathrm{X}=\mathrm{NMe}, \mathrm{R}=\mathrm{F})$, bound with high affinity and selectivity to sigma-2 receptors (Table $1 ; K_{\mathrm{i}}=$ $101 \mathrm{nM}$ at sigma-1 receptors; $K_{\mathrm{i}}=6.1 \mathrm{nM}$ at sigma-2 receptors). When the effect of treatment with the fluorinesubstituted ligand on cell viability was examined, no significant cytotoxicity was induced (data not shown). Instead, a metabolic stimulation effect was observed (see below). These results demonstrate that the strong electron-withdrawing character of the isothiocyanate group alone is not sufficient 


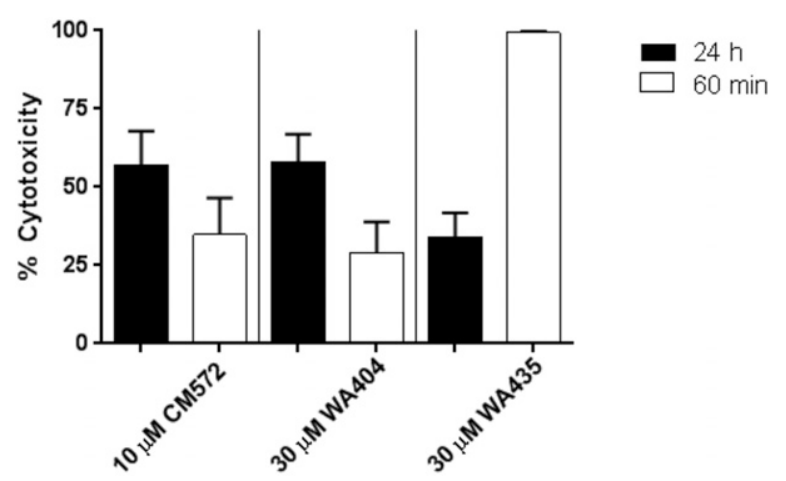

Fig. 6. Comparison of acute and continuous exposure to isothiocyanatesubstituted ligands on cell viability of SK-N-SH neuroblastoma. Cells were plated at 15,000 cells/well and allowed to attach overnight prior to dosing with indicated concentration of each ligand. Cells were incubated with the indicated ligand continuously for 24 hours (black bars) or cells were treated with ligand for 60 minutes followed by extensive washing with fresh media and 24 hours of incubation in ligand-free media (white bars). At the end of the 24-hour period, viable cells remaining were determined by MTT assay. Treatment with all three isothiocyanate derivatives resulted in either comparable or greater levels of cell death in the acute exposure experiment as with 24 hours of continuous exposure $(P$ $=0.13,0.056$, and 0.003 , respectively, for CM572, WA404, and WA435 comparisons of the two exposure conditions, Student's $t$ test). These data indicate that the isothiocyanate-substituted ligands continue to induce cell death as a result of their capacity to irreversibly bind sigma-2 receptors even after free ligand is removed. Results are presented as the percentage of cells killed in response to each treatment compared with untreated control cells. Data are presented as an average \pm S.D. of three independent experiments for each condition for each ligand. All experiments were performed with five replicates per condition.

to induce significant levels of cell death, whereas irreversible binding was sufficient to induce cytotoxicity.

Another possible explanation for the observation that the isothiocyanate derivatives are the most potent cytotoxic ligands is that the effect is due to a nonspecific off-target effect of the isothiocyanate and that the sigma-2 receptor is playing no role. The NCS moiety could be attacked by a nucleophile on any protein, which could result in general toxicity to the cell, especially in the higher-micromolar range. We examined this by assessing the effect of phenylisothiocyanate (PhNCS) on sigma receptor binding and SK-N-SH cell viability. PhNCS would not be expected to exhibit sigma receptor affinity, but should readily enter cells and potentially be attacked by protein nucleophiles. Figure 7A shows that PhNCS indeed had no appreciable effect on sigma-1 or sigma-2 receptor binding at concentrations up to $100 \mu \mathrm{M}$. Figure 7B shows the effect of $\mathrm{PhNCS}$ on cell viability in media with two concentrations of FBS, $2 \%$ and the normal 10\%. High and low concentrations of FBS were used to examine possible serum effects on the NCS group, though the concentration of FBS was found to have no effect on the activity of CM572 $(\mathrm{X}=\mathrm{O}, \mathrm{R}=\mathrm{NCS})$ in our previous study (Nicholson et al., 2015). There was no significant cytotoxic effect of PhNCS on SK-N-SH cells. A dose of $10 \mu \mathrm{M}$ induced no significant cytotoxic effect, and there was $<25 \%$ cytotoxicity at $100 \mu \mathrm{M}$ PhNCS over a 24-hour incubation period at either FBS concentration. Taken together, the data show that specifically targeting the isothiocyanate to the sigma-2 receptor is necessary to affect both binding activity and cytotoxic efficacy of the isothiocyanate SN79 derivatives. Thus, it appears that irreversible sigma-2 receptor binding activity imparted by the isothiocyanate moiety may play a key role in the cell death-inducing activity of these analogs.

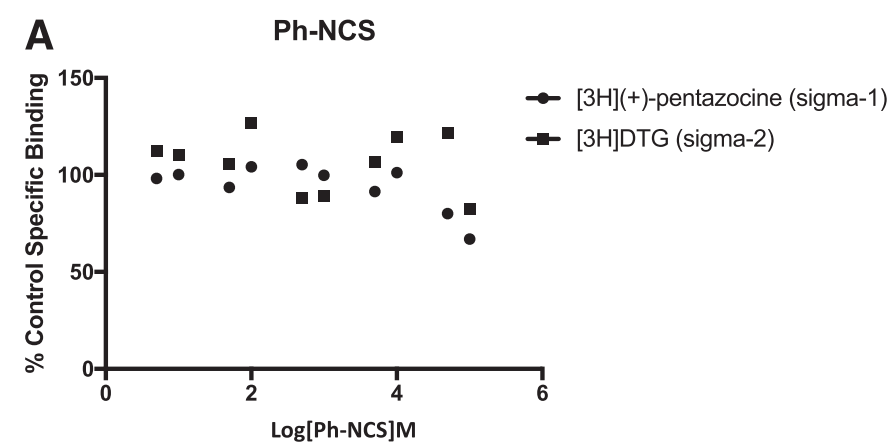

\section{B Ph-NCS}

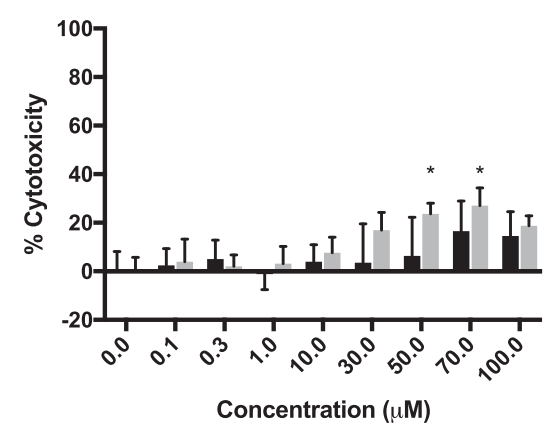

Fig. 7. Binding of phenyl isothiocyanate at sigma receptors and effect on viability of SK-N-SH neuroblastoma. (A) Sigma-1 and sigma-2 receptor binding was determined by competition of phenyl isothiocyanate with $\left[{ }^{3} \mathrm{H}\right]$ (+)-pentazocine or $\left[{ }^{3} \mathrm{H}\right] \mathrm{DTG}$ in the presence of unlabeled (+)-pentazocine, respectively. No significant binding at sigma-1 or sigma-2 receptors was observed upon competition with phenyl isothiocyanate. Experiments were performed in duplicate. (B) Cells were plated at 15,000 cells/well and allowed to attach overnight prior to treatment with the indicated concentrations of phenyl isothiocyanate for 24 hours, followed by MTT assay. No significant cytotoxicity was observed in $2 \%$ serum conditions, and only very high concentrations of phenyl isothiocyanate reached significance in $10 \%$ serum conditions compared with untreated cells (twoway ANOVA Dunnett's multiple-comparisons post hoc test, $* P<0.05$ compared with untreated cells).

Effect of Ligand Treatment on Metabolic Reduction of MTT. We have recently described a novel, nontoxic, nonzero function for sigma-2 receptors using the SN79 derivative CM764 (Nicholson et al., 2016). Five of the ligands investigated in this series replicated this effect, inducing an increase in the reduction of MTT upon 24 hours of treatment compared with untreated cells. Results are shown in Fig. 8. The five ligands (CM458, CM571, NF7, WA504, and WA379) that promoted significantly increased MTT reduction in SK-N-SH neuroblastoma all had high sigma-2 receptor binding affinity, with receptor subtype selectivity varying widely. These compounds have R-group substitutions representing all possibilities examined except $\mathrm{R}=\mathrm{NCS}$, which was shown to be toxic in all cases, as described above. Additionally, this subset of five ligands encompasses all three possible X-group substitutions examined. These data indicate that neither $\mathrm{X}$ group nor $\mathrm{R}$ group alone determine the ability to induce an increased reduction of MTT.

\section{Discussion}

The goal of this study was to establish a relationship among ligand structure, binding affinity and selectivity, and the 


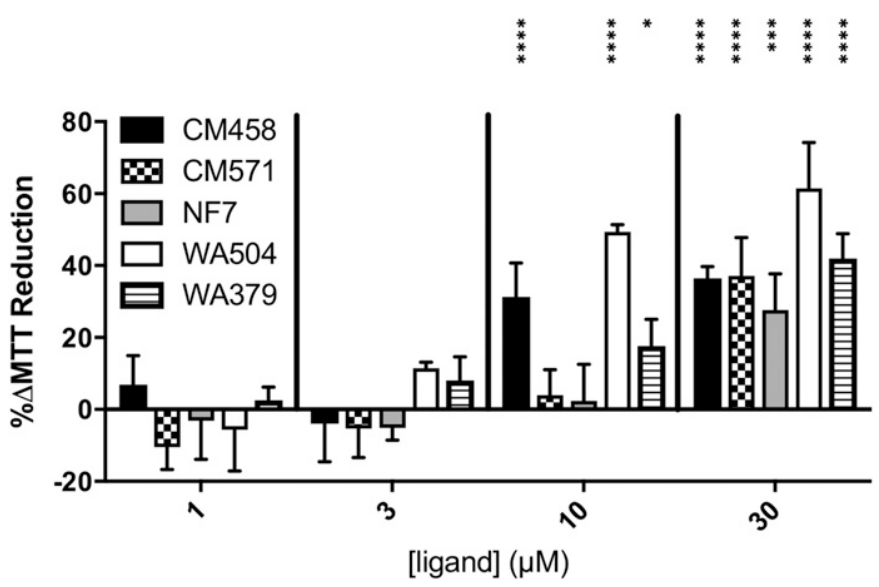

Fig. 8. Ability of SN79 derivatives to increase the reduction of MTT in SK-N-SH neuroblastoma. Cells were plated at 15,000 cells/well and allowed to attach overnight prior to treatment with the indicated ligand and concentration for 24 hours, followed by MTT assay. Five of the 12 SN79 derivatives in this series demonstrated the ability to induce a significant increase in the amount of MTT reduced compared with untreated cells (two-way ANOVA, overall $P<0.0001$; Dunnett's multiple-comparisons post hoc test $* P<0.05$; *** $P<0.001$; **** $P<$ 0.0001 compared with untreated cells). All R-group substitutions were represented except $R=\mathrm{NCS}$, which is consistent with the ability of $\mathrm{R}=$ NCS ligands to induce cell death. All X-group substitutions were also represented in this subset, and all ligands demonstrated high sigma-2 receptor binding affinity. Results are presented as the percentage change in MTT reduction compared with an untreated control, which was normalized to zero. Data are presented as an average \pm S.D. of at least three independent experiments for each condition, with each experiment performed using five replicates per condition.

functional efficacy of a series of novel SN79 derivatives at sigma-1 and sigma-2 receptors. The parent compound SN79 displays approximately 4-fold selectivity for the sigma-2 receptor over sigma-1 and has been screened for off-target binding without any significant hits (Kaushal et al., 2011). SN79 is a sigma-2 receptor antagonist and does not induce cell death even at high doses (Garcia, 2012). As one of the few sigma-2-selective ligands that has been thoroughly characterized, this was a natural starting point for the development of additional sigma-2 receptor-selective ligands with which to study structural parameters affecting receptor affinity and the ability to induce either cell death or a metabolically stimulative effect in SK-N-SH neuroblastoma cells. We synthesized a series of ligands with single-moiety changes using the core structure of SN79 to examine these relationships.

Table 1 shows binding affinity of the analogs at sigma-1 and sigma-2 receptors. Affinity at sigma-1 receptors was significantly decreased for ligands with $\mathrm{X}=\mathrm{NMe}$ substitutions, suggesting potential steric strain at this position in the binding pocket of the sigma-1 receptor (Fig. 1). Sterically smaller $\mathrm{X}$-group substitutions $(\mathrm{X}=\mathrm{O}$ and $\mathrm{X}=\mathrm{S})$ did not result in a general decrease in sigma-1 receptor binding affinity, lending strength to this hypothesis. Another possibility is that the sigma-1 receptor binding pocket may have an ideally situated hydrogen bond donor that the $\mathrm{X}=\mathrm{O}$ and, to a weaker extent, the $\mathrm{X}=\mathrm{S}$ substitutions could participate in to promote higher affinity binding. However, this is a less likely cause as $\mathrm{X}=\mathrm{S}$ substitutions had generally higher-affinity binding, yet sulfur is a much weaker hydrogen bond acceptor than oxygen. Another factor that demonstrated a decrease in sigma-1 receptor binding affinity is the isothiocyanate $\mathrm{R}$-group substitution. Derivatives with $\mathrm{R}=$ NCS generally had lower affinity for the sigma-1 receptor compared with the other substitutions, which resulted in a trend of increased selectivity for the sigma-2 receptor. All ligands in this series except CM571 $\left(\mathrm{X}=\mathrm{O}, \mathrm{R}=\mathrm{NH}_{2}\right.$ ) demonstrated at least slight selectivity for the sigma-2 receptor, which was maintained from the parent compound SN79.

Sigma-2 receptor binding affinity was increased for ligands with $\mathrm{R}=\mathrm{NO}_{2}$ substitutions (Fig. 2) and independently for ligands with $\mathrm{X}=\mathrm{S}$ substitutions (Fig. 3). The $\mathrm{X}=\mathrm{S}$ substitution also generally resulted in an increase in affinity at sigma-1 receptors (although to a lesser extent), which resulted in reduced sigma-2 receptor selectivity. However, compared with sigma-1 affinity, sigma-2 receptor affinity appears to be less dependent on interplay between X- and R-group substituents, with compounds generally having high affinity at sigma-2 receptors. These results are consistent with the ligand core structure, in which the $\mathrm{X}$ position and the $\mathrm{R}$ position are conjugated. Therefore, resonance allows for changes in the $\mathrm{X}$ group to affect electron density at the $\mathrm{R}$ position, and vice versa.

Substitution of the $\mathrm{R}$ group with an isothiocyanate allowed for the possibility of irreversible binding if there were an ideally positioned amine (lysine) or thiol (cysteine) group in the binding pocket of the receptor. This irreversible binding capability was confirmed by measuring recovered radioligand binding after pretreatment with isothiocyanate-substituted ligands followed by washout of any nonirreversibly bound ligand. All isothiocyanate-substituted ligands were able to irreversibly bind sigma- 2 receptors, whereas only WA404 (X = $\mathrm{NMe}, \mathrm{R}=\mathrm{NCS}$ ) showed any ability to irreversibly bind sigma1 receptors, and not with high potency. This indicates that the isothiocyanate in the $R$ position may be ideally placed for covalent bond formation in the sigma-2 receptor binding pocket, but not in the sigma-1 receptor binding pocket.

Interestingly, only $\mathrm{R}=\mathrm{NCS}$ substituted ligands in this series were able to induce significantly potent levels of cell death in SK-N-SH neuroblastoma, indicating agonist activity (Fig. 5). This ability to induce cell death appears to be a result of the capacity to irreversibly bind sigma-2 receptors, rather than a result of the highly electronwithdrawing group in the $\mathrm{R}$-group position, as neither $\mathrm{R}=$ $\mathrm{NO}_{2}$ substituted ligands nor an $\mathrm{R}=\mathrm{F}$ substituted ligand were able to induce significant cell death in a comparable concentration range. These data indicate that irreversible binding is sufficient to induce cytotoxicity, whereas simply having a highly electron-withdrawing group in the same position is not. Furthermore, cytotoxicity of the isothiocyanate required specific targeting to the sigma-2 receptor, since phenyl isothiocyanate, which lacks sigma receptor affinity, had little effect on cell viability. Interestingly, although irreversible binding may play some role with SN79 analogs, irreversible binding is clearly not required for sigma-2 receptor-induced cell death in compounds from other structural classes, such as CB-64D, siramesine, and SV119, that lack an NCS group and the ability to bind covalently.

We surmised that irreversible sigma-2 binding would impart long-lasting effects on sigma-2 receptor function. When SK-N-SH cells were acutely treated with isothiocyanatesubstituted ligands for 60 minutes followed by extensive washing and 24 hours of incubation in media without free ligand, the levels of cytotoxicity achieved were comparable to 


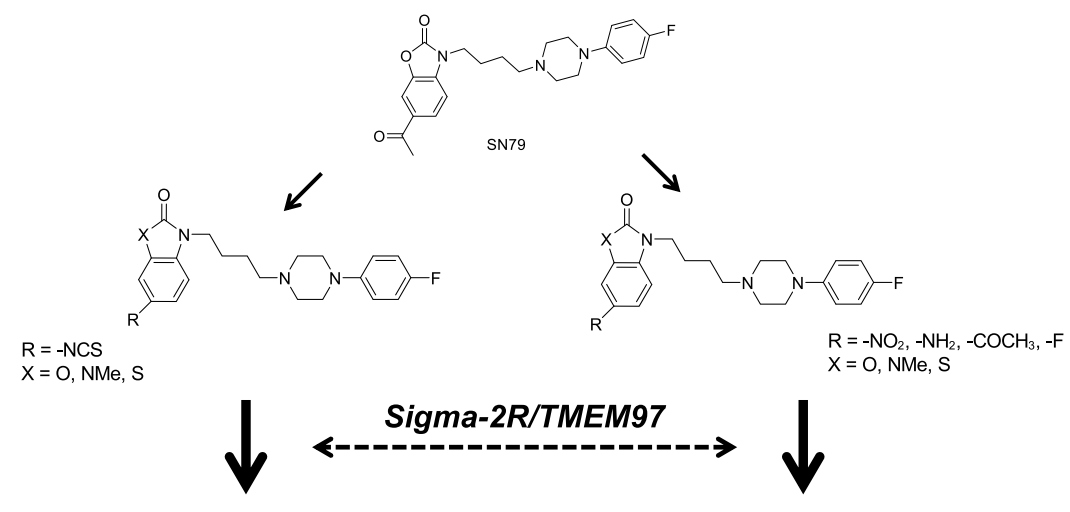

Fig. 9. Divergent effects of SN79 analogs. Diagram shows the structural relationship of compounds examined in this study and the effects that are elicited. SN79 is shown as the parent compound. The heterocyclic $\mathrm{X}$-atom was varied as $\mathrm{O}$ (benzoxazolone), N-methyl ( $N$-methylbenzimidazolone), and $\mathrm{S}$ (benzothiazolone). The R-group in the 6-position was substituted with isothiocyanato, nitro, amine, methylketone, or fluorine. Only compounds with $\mathrm{R}=\mathrm{NCS}$, regardless of heterocycle, were able to potently induce programmed cell death. Several compounds with the other 6-position substituents were metabolic stimulators, regardless of heterocycle. Other nonisothiocyanates, including SN79 itself, were neutral, producing neither programmed cell death nor metabolic stimulation at concentrations up to $30 \mu \mathrm{M}$. The dotted line linking the groups indicates that both effects appear to be mediated by sigma-2R/TMEM97.

\section{Programmed Cell Death}

Metabolic Stimulation

those after 24 hours of continuous incubation with ligand for both CM572 ( $\mathrm{X}=\mathrm{O}, \mathrm{R}=\mathrm{NCS})$ and WA404 (X = NMe, $\mathrm{R}=$ NCS) (Fig. 6). This indicates that the ability to irreversibly bind sigma-2 receptors also imparts the ability to continue to activate these receptors and induce cytotoxicity without free ligand present in the media. WA435 $(\mathrm{X}=\mathrm{S}, \mathrm{R}=\mathrm{NCS})$ was found to induce cell death more potently when acutely treated and then incubated in media without free ligand for 24 hours compared with 24 hours of continuous exposure to ligand. WA435 is the only isothiocyanate ligand that retains significant affinity for the sigma-1 receptor, although it does not irreversibly bind the sigma-1 subtype. This may explain the increased potency in the acute treatment. If WA435 is a sigma1 agonist, then 24 hours of continuous exposure would allow continuous occupancy of the sigma- 1 receptor, activation of which is known to promote cell survival (Hayashi and $\mathrm{Su}$, 2007; Wu and Bowen, 2008). This could therefore compete with the cytotoxic effect of sigma-2 receptor activation. In the acute treatment, all ligand would be washed out of sigma-1 receptors, and this prosurvival pathway would no longer be activated. Whether covalent attachment to the receptor via the 6-isothiocyanato moiety is key to cytotoxicity will require further study.

We have recently shown the ability of a novel SN79 derivative, CM764, to induce a nontoxic, nonzero effect through the sigma-2 receptor, comprising in part the stimulation of MTT reduction (Nicholson, et al., 2016). In the current series, 5 of the 13 SN79 derivatives shared this CM764-like phenotype with respect to the stimulation of MTT reduction. Although it is difficult to determine a very clear relationship between the structure and the ability to increase MTT reduction in SK-N-SH neuroblastoma cells, our data show some trends. High sigma-2 receptor affinity was a common factor for all ligands with this function. Neither $\mathrm{R}$-group alone nor X-group alone could explain the relationship between ligand structure and the ability to induce increased MTT reduction, as compounds representing all X substitutions and R substitutions (with the exception of NCS) caused MTT stimulation. Furthermore, there are also "neutral" compounds. For example, $\mathrm{SN79}\left(\mathrm{X}=\mathrm{O}, \mathrm{R}=\mathrm{COCH}_{3}\right)$ itself neither kills cells nor induces significant stimulation of metabolism at $30 \mu \mathrm{M}$ (Nicholson et al., 2016). In fact, $30 \mu \mathrm{M}$ SN79 was able to completely attenuate the metabolic stimulation induced by $10 \mu \mathrm{M}$ CM764. This, along with complete blockade by a low, subcytotoxic dose $(300 \mathrm{nM})$ of the highly sigma-2 receptor-selective CM572, contributed to supporting evidence that the stimulatory effect is mediated by sigma-2 receptors (Nicholson et al., 2016). Also, the only difference between the neutral SN79 and metabolic stimulative CM458 and CM571 is $\mathrm{NO}_{2}$ or $\mathrm{NH}_{2}$ in the 6-position, respectively, versus $\mathrm{COCH}_{3}$. Thus, subtle changes in structure have marked effects on compound efficacy. It seems probable that these phenotypes derive from a combinatorial effect. The $\mathrm{X}$ group and $R$ group are conjugated in the series investigated in this study, and therefore both positions could contribute to the development of this stimulative function. In addition, with $\mathrm{CM} 764, \mathrm{X}=\mathrm{O}, \mathrm{R}=\mathrm{COCH}_{3}$, and there is an amine moiety in the fluorophenyl ring, indicating that modifications of the other ring system also affect the stimulatory efficacy. Further studies on the combinatorial effects and electron density changes with additional X-group and R-group substitutions may help to elucidate this relationship.

The results of this study show that sigma-2 receptor ligands in the SN79-related platform can be divided into two activity classes: those that induce programmed cell death and those that stimulate MTT reduction (metabolic stimulation). This is summarized in Fig. 9. A third class may be those compounds that are neutral and possibly antagonists. We have postulated that the metabolic stimulation effect (as first characterized in detail with CM764) (Nicholson et al., 2016) may be related to a survival role, consistent with the upregulation of sigma-2 receptors in cancer cells, and involved in the enhancement of tumor cell adaptation in a hypoxic environment. It is not yet clear how the sigma-2 receptor mediates both the induction of apoptosis and this nontoxic effect on metabolism. SN79 analogs will be helpful in resolving this issue.

\section{Authorship Contributions}

Participated in research design: Nicholson, Comeau, and Bowen. Conducted experiments: Nicholson and Comeau.

Contributed new reagents or analytic tools: Alsharif, Mesangeau, Intagliata, Mottinelli, and McCurdy.

Performed data analysis: Nicholson and Comeau.

Wrote or contributed to the writing of the manuscript: Nicholson and Bowen.

\section{References}

Abate C, Niso M, Infantino V, Menga A, and Berardi F (2015) Elements in support of the 'non-identity' of the PGRMC1 protein with the $\sigma 2$ receptor. Eur $J$ Pharmacol 758:16-23.

Ahmed IS, Rohe HJ, Twist KE, Mattingly MN, and Craven RJ (2010) Progesterone receptor membrane component 1 (Pgrmc1): a heme-1 domain protein that promotes 
tumorigenesis and is inhibited by a small molecule. J Pharmacol Exp Ther 333: $564-573$.

Alon A, Schmidt HR, Wood MD, Sahn JJ, Martin SF, and Kruse AC (2017) Identification of the gene that codes for the $\sigma_{2}$ receptor. Proc Natl Acad Sci USA 114: $7160-7165$

Chu UB, Mavlyutov TA, Chu M-L, Yang H, Schulman A, Mesangeau C, McCurdy CR, Guo L-W, and Ruoho AE (2015) The sigma-2 receptor and progesterone receptor membrane component 1 are different binding sites derived from independent genes. EBioMedicine 2:1806-1813.

Crawford KW and Bowen WD (2002) Sigma-2 receptor agonists activate a novel apoptotic pathway and potentiate antineoplastic drugs in breast tumor cell lines. Cancer Res 62:313-322.

Garcia DR (2012) Sigma-2 Receptor-Mediated Cytotoxicity and Calcium Signaling: Evidence for Bifurcating Pathways. Ph.D. thesis, Brown University, Providence, RI

Hayashi T and Su T-P (2007) Sigma-1 receptor chaperones at the ER-mitochondrion interface regulate $\mathrm{Ca}(2+)$ signaling and cell survival. Cell 131:596-610.

Hazelwood S and Bowen WD (2006) Sigma-2 receptor-mediated apoptosis in human SK-N-SH neuroblastoma cells: role of lipid rafts, caspases, and mitochondrial depolarization. Cancer Res 66:4932.

Hellewell SB and Bowen WD (1990) A sigma-like binding site in rat pheochromocytoma (PC12) cells: decreased affinity for (+)-benzomorphans and lower molecular weight suggest a different sigma receptor form from that of guinea pig brain. Brain Res 527:244-253.

Hellewell SB, Bruce A, Feinstein G, Orringer J, Williams W, and Bowen WD (1994) Rat liver and kidney contain high densities of sigma-1 and sigma-2 receptors: characterization by ligand binding and photoaffinity labeling. Eur $J$ Pharmacol 268:9-18.

Izzo NJ, Staniszewski A, To L, Fa M, Teich AF, Saeed F, Wostein H, Walko T III, Vaswani A, Wardius M, et al. (2014a) Alzheimer's therapeutics targeting amyloid beta 1-42 oligomers I: Abeta 42 oligomer binding to specific neuronal receptors is displaced by drug candidates that improve cognitive deficits. PLoS One 9:e111898.

Izzo NJ, Xu J, Zeng C, Kirk MJ, Mozzoni K, Silky C, Rehak C, Yurko R, Look G, Rishton G, et al. (2014b) Alzheimer's therapeutics targeting amyloid beta 1-42 oligomers II: sigma-2/PGRMC1 receptors mediate Abeta 42 oligomer binding and synaptotoxicity. PLoS One 9:e111899.

Kaushal N, Robson MJ, Vinnakota H, Narayanan S, Avery BA, McCurdy CR, and Matsumoto RR (2011) Synthesis and pharmacological evaluation of 6-acetyl-3(4-(4-(4-fluorophenyl)piperazin-1-yl)butyl)benzo[d]oxazol-2(3H)-one (SN79), a cocaine antagonist, in rodents. AAPS J 13:336-346.

Lösel RM, Besong D, Peluso JJ, and Wehling M (2008) Progesterone receptor membrane component 1--many tasks for a versatile protein. Steroids 73:929-934.

Mach RH, Smith CR, al-Nabulsi I, Whirrett BR, Childers SR, and Wheeler KT (1997) Sigma-2 receptors as potential biomarkers of proliferation in breast cancer. Cancer Res 57:156-161.

Mach RH and Wheeler KT (2009) Development of molecular probes for imaging sigma-2 receptors in vitro and in vivo. Cent Nerv Syst Agents Med Chem 9: $230-245$.

Neubauer H, Adam G, Seeger H, Mueck AO, Solomayer E, Wallwiener D, Cahill MA, and Fehm T (2009) Membrane-initiated effects of progesterone on proliferation and activation of VEGF in breast cancer cells. Climacteric 12:230-239.
Nicholson H, Comeau A, Mesangeau C, McCurdy CR, and Bowen WD (2015) Characterization of CM572, a selective irreversible partial agonist of the sigma-2 receptor with antitumor activity. J Pharmacol Exp Ther 354:203-212.

Nicholson H, Mesangeau C, McCurdy CR, and Bowen WD (2016) Sigma-2 receptors play a role in cellular metabolism: stimulation of glycolytic hallmarks by CM764 in human SK-N-SH neuroblastoma. J Pharmacol Exp Ther 356:232-243.

Peluso JJ, Liu X, Gawkowska A, Lodde V, and Wu CA (2010) Progesterone inhibits apoptosis in part by PGRMC1-regulated gene expression. Mol Cell Endocrinol 320: 153-161.

Sahlholm K, Liao F, Holtzman DM, Xu J, and Mach RH (2015) Sigma-2 receptor binding is decreased in female, but not male, APP/PS1 mice. Biochem Biophys Res Commun 460:439-445.

Shoghi KI, Xu J, Su Y, He J, Rowland D, Yan Y, Garbow JR, Tu Z, Jones LA, Higashikubo R, et al. (2013) Quantitative receptor-based imaging of tumor proliferation with the sigma-2 ligand [(18)F]ISO-1. PLoS One 8:e74188.

Vilner BJ and Bowen WD (2000) Modulation of cellular calcium by sigma-2 receptors: release from intracellular stores in human SK-N-SH neuroblastoma cells. $J$ Pharmacol Exp Ther 292:900-911.

Vilner BJ, John CS, and Bowen WD (1995) Sigma-1 and sigma-2 receptors are expressed in a wide variety of human and rodent tumor cell lines. Cancer Res 55: 408-413.

Wang X and Bowen WD (2006) Sigma-2 receptors mediate apoptosis in SK-N-SH neuroblastoma cells via caspase-10-dependent Bid cleavage and mitochondrial release of endonuclease G and apoptosis-inducing factor. 2006 Neuroscience Meeting Planner: Program No. 90.1. Society for Neuroscience Annual Meeting, October 14-18; Atlanta, GA. Society for Neuroscience, Washington DC

Wheeler KT, Wang LM, Wallen CA, Childers SR, Cline JM, Keng PC, and Mach RH (2000) Sigma-2 receptors as a biomarker of proliferation in solid tumours. $\mathrm{Br} J$ Cancer 82:1223-1232.

Wu Z and Bowen WD (2008) Role of sigma-1 receptor C-terminal segment in inositol 1,4,5-trisphosphate receptor activation: constitutive enhancement of calcium signaling in MCF-7 tumor cells. J Biol Chem 283:28198-28215.

Xu J, Zeng C, Chu W, Pan F, Rothfuss JM, Zhang F, Tu Z, Zhou D, Zeng D, Vangveravong $\mathrm{S}$, et al. (2011) Identification of the PGRMC1 protein complex as the putative sigma-2 receptor binding site. Nat Commun 2:380.

Yi B, Sahn JJ, Ardestani PM, Evans AK, Scott LL, Chan JZ, Iyer S, Crisp A, Zuniga G, Pierce JT, et al. (2017) Small molecule modulator of sigma 2 receptor is neuroprotective and reduces cognitive deficits and neuroinflammation in experimental models of Alzheimer's disease. J Neurochem 140:561-575.

Zeng C, Rothfuss JM, Zhang J, Vangveravong S, Chu W, Li S, Tu Z, Xu J, and Mach $\mathrm{RH}$ (2014) Functional assays to define agonists and antagonists of the sigma-2 receptor. Anal Biochem 448:68-74.

Zeng C, Vangveravong S, Jones LA, Hyrc K, Chang KC, Xu J, Rothfuss JM, Goldberg MP, Hotchkiss RS, and Mach RH (2011) Characterization and evaluation of two novel fluorescent sigma-2 receptor ligands as proliferation probes. Mol Imaging 10: 420-433.

Address correspondence to: Dr. Wayne D. Bowen, 171 Meeting Street, Box G-B389, Providence, RI 02912. E-mail: Wayne_Bowen@brown.edu 